\title{
A DRAWING FOR THE FABRICA; AND SOME THOUGHTS UPON THE VESALIUS MUSCLE-MEN
}

by

\author{
MARTIN KEMP
}

THE wOODCuTs, over two hundred and fifty in number, published in the first edition of Andreas Vesalius's De Humani Corporis Fabrica libri septem (1543) are arguably the most important of all illustrations in the history of medical science. ${ }^{1}$ Many of the plates, most notably the fourteen muscle-men in book two, are also remarkable for their high degree of artistic accomplishment. The authorship of the illustrations has been the subject of a seemingly endless controversy-a controversy which has been notable for its large percentage of loosely speculative conjectures, rather than for any reasoned discussion of the available (if meagre) evidence. ${ }^{2}$ The one point to have emerged clearly is the desperate need for further evidence of a primary, factual nature: the title-page of the Fabrica provides no acknowledgement of the artist(s) responsible; the earliest certain reference (Vasari, 1568) to the possible designer dates from a full quarter-century after the first edition; no genuine preparatory drawings for the anatomical plates have been shown to exist, and the apparently genuine studies for the title-page have not been identifiable with the work of a known draughtsman. ${ }^{3}$ However, an isolated preparatory study for one of the all-important muscle-men has survived (and remained unpublished) in the Munich collection of Rudolph S. Joseph (fig. 1). In addition to its obvious relevance to the attribution problems, the drawing throws significantly fresh light upon the planning of the plates, most particularly upon the brilliantly and minutely subtle choreography of the muscular 'ballet' in book two-a factor which has been all but overlooked.

The drawing (red chalk upon slightly discoloured white paper) has been broken by a horizontal fold across its centre, but the crisp draughtsmanship of the figure itself is excellently preserved." The figure closely corresponds, in reverse, to the 'Secunda musculorum tabula' on page 174 of the first edition of the Fabrica (fig. 2). A number of minor differences can be discerned: the transverse ligaments of the wrist and ankle are omitted in the drawing; the tendons of the feet are more clearly delineated in the plate, and the head of the engraved figure is anatomized in greater

\footnotetext{
1 The first edition was printed by Ioannes Oporinus (Herbst) in Basle and published in Venice. To accompany the Fabrica, Vesalius published an Epitome, which was later to become more popular than the Fabrica itself. The smaller work contained eight anatomical plates (brilliantly condensed from the Fabrica), one skeletal plate taken directly from the Fabrica, and two new plates of the external appearance of the human figuro - eleven in all.

: The most recent rehearsal of this evidence is to be found in F. Guerra's 'The identity of the artists involved in Vesalius's Fabrica 1543', Med. Hist., 1969, 13, 37-50. Guerra includes a useful bibliography, but his interpretation of Vasari's texts must be treated with the greatest caution. See also J. B. de C. M. Saunders and C. D. O'Malley, The Illustrations from the Works of Andreas Vesalius of Brussels, Cleveland and New York, 1950; and W. M. Ivins jr., Three Vesalian Essays to Accompany the 'Icones Anatomicae' of 1934, New York, 1952.

Three drawings can be associated with the title-page. See Saunders and O'Malley, op. cit., pls. 93-96.

- The watermark, a curved horn, cannot be traced, though similar ones were in common use during the fifteenth and sixteenth centuries (Briquet 7680-88).
} 


\section{Martin Kemp}

detail. But the major features of the musculature are similarly displayed. The absence from the drawing of the lettering and the landscape can easily be reconciled with its possible preliminary function in the development of the plate. The red chalk figure measures $34.5 \mathrm{~cm}$. from the crown of the head to the sole of the heel; the woodcut man is $34 \mathrm{~cm}$. tall.

In addition to its obvious similarities to the second plate, the drawing exhibits unexpectedly close relationships with other plates in the muscle-man book. These relationships are, as I hope to show, of such intricacy that the form of the drawing can only be satisfactorily explained if it is regarded as an integral part of an extraordinarily complicated creative process. The drawing cannot, therefore, easily be dismissed as the product of a copyist working from the published treatise. Also, it is difficult to believe that a copyist would have specially reversed and modified the figure.

On the other hand, the series of line-and-wash studies (Hunterian Museum, University of Glasgow), regarded as genuine by Saunders and O'Malley, should not be accepted at face value as a set of preparatory studies for the Fabrica. ${ }^{5}$ For a number of reasons, the Glasgow drawings could not have played any useful role in the creation of the treatise-either in the preliminary delineation of the dissections or in the detailed planning of the book itself. The lettering on the drawings has been meaninglessly appended to figures in which the corresponding details are not shown with the clarity necessary for such labelling; the figures are extremely weakly executed, their articulation possessing none of the convincing firmness of the plates; and, in a number of cases, diagrams and portions of text from different parts of the Fabrica have been illogically rearranged together on the same sheet. Beside one of the transposed diagrams is the inscription 'ex libro secundo'-a clear acknowledgement of its relationship to the published treatise. ${ }^{6}$ With the exception of the very different study for the title-page, the Hunterian volume appears to contain no more than a series of relatively unskilled tracings and transcriptions from the original edition.

The documentation of Vesalius's collaboration with the illustrators of his treatises is far from complete, but certain clues can be gleaned, particularly concerning Vesalius's own role.

Vesalius published his first major set of anatomical illustrations, the Tabulae Sex, in April 1538. The introduction on the first plate and the colophon on the sixth (fig. 3) are quite explicit as to the authorship of the designs. The first three plates, based upon the novel charts of the blood vessels which Vesalius had used in teaching, were executed directly from Vesalius's own designs. The three views of the skeleton'recently constructed for the pleasure of students'-which involved more complex draughtsmanship, 'were appropriately represented from three directions by Ioannes Stephanus [Jan Steven van Kalkar], a notable painter of our day'. ${ }^{7}$ The 'Skeleton a

- A case for rejecting the Glasgow drawings was made by Ivins, op. cit., pp. 125-26. For the slender evidence in favour of their authenticity, see H. Cushing, A Bio-Bibliography of Andreas Vesalius, New York, 1943, p. 82 and fig. 14. The volume in which these drawings are bound (together with the apparently genuine drawing for the title-page) was purchased by William Hunter in 1755 .

- Page XVIV of the Hunterian Volume. The text for the fourth muscle-man is followed by the diagram 'de Musculis peni peculiare' from twenty pages later in the published work.

7 Tabulae Sex, Venice, 1538, pl. 1: "certerum cum plurimi hec fustra imitari conarentur, rem

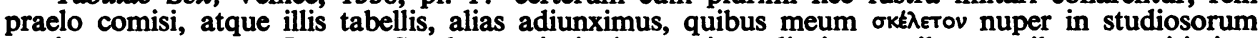
gratiam constructum, Ioannes Stephanus, insignis nostri seculi pictor, tribus partibus appositissime expressit.' 


\section{A Drawing for the Fabrica; and Some Thoughts upon the Vesalius Muscle-men}

tergo delineatuum' carries the further information that the plates were 'printed in Venice by B. Vitalis, at the expense of Ioannes Stephani Calcarensis: for sale at the workshop of D. Bernardi' ${ }^{8}$ Presumably an enterprise of this novelty was considered a risky financial undertaking for the printer; and Vesalius himself may have been unable to finance the printing at this early stage of his Italian career.

At the end of his introduction to the Tabulae, Vesalius expressed his intention to 'add something greater some day', provided that the six plates were well received. A year later, in his Venesection Letter, which contained another of his own vessel charts, Vesalius recorded that this greater project was well under way. In collaboration with an engraver or designer, he had completed two plates of the nerves-almost certainly numbers one and ten in book four-but he stated his intention to retain these until the plates of the muscles and internal organs had been undertaken. ${ }^{9}$ For this purpose, Vesalius indicated that he would again endeavour to secure the services of Jan Steven van Kalkar; but there is no subsequent reference in Vesalius's writings to Kalkar or to any other designer for the Fabrica. ${ }^{10}$

The two diagrams completed before Kalkar's possible intervention are introduced with 'we have drawn' and 'we have represented', phrases which suggest his prior co-operation with another artist. But these early nerve plates are not drawn with the high degree of skill necessary for the design of the muscle-men. In a few other cases, Vesalius appears to have deliberately indicated his own authorship of certain designs, by his exceptional use of the first person singular in the introductions: 'I have sketched' and 'I have represented'.11 Vesalius's own plates are competently drawn, but they in no way suggest that he could himself have been the draughtsman of the muscle-men.

To establish the identity of the designer(s) of the plates for which Vesalius himself was not responsible, we have to fall back upon secondary sources. The second edition of Giorgio Vasari's Vite (1568) contains the first definite pronouncements on the question of authorship. In three entirely separate sections of the Vite, he specifically indicated that 'Giovanni Calker, pittore fiammingo' had designed anatomical plates for the Fabrica or for the Epitome. The first of these accounts is to be found in the Vita of 'Marcantonio Raimondi e Altri Intagliatore di Stampe'; the second in his discussion of Titian's bottega, and the last in his section entitled 'Di Diversi Artisti Fiamminghi'. ${ }^{12}$ Vasari's reference, in the first account, to 'eleven large sheets of

8 'Impremabat Venetys B. Vitalis sumptibus Ioannis Stephani Calcarensis. Prostrant vero in officina D. Bernardi.'

- See Saunders and O'Malley, op. cit., p. 19.

${ }_{10}$ For the chronology of the Fabrica, see ibid., pp. 19-21.

11 For example, Book III, no. vi; V, x; and V, xxx.

12 G. Vasari, Le vite de' più eccellenti architetti, pittori e scultori Italiani, ed. G. Milanesi, Florence, 1878-85, V p. 435, VII pp. 460-1, and VII p. 582, respectively:

a) 'Non furono anco se non lodevoli le figure che Gabriel Giolito, stampatore de' libri, mise negli Orlandi Furiosi, perioche furono condotte con bella maniera d'intagli: come furono anco gli undici pezzi di carte grande di notomia, che furono fatte de Andrea Vesalio, e disegnate da Giovanni Calcare fiammingo, pittore eccellentissimo; le quali furono poi ritratte in minor foglio, ed intagliate in rame da Valverde, che scrisse della notomia dopo il Vesalio.'

b) 'E stato con esso lui, fra gli altri, un Giovanni Fiammingo, che di figure cosi piccole come grande, e stato assai lodati maestro, a nei ritratte maraviglioso, come si vede in Napoli, dove e vivuto alcun tempo e finalmente morto. Furono di man di costui (il che dovera in tutti i tempi essere d'onore) i disegni dell' anatomie, che fece intagliare e mandar fuori con la sua opera eccellentissime Andrea Vesalio.'

c) 'Cannobi ancora in Napoli, e fu mio amicissimo, l'anno 1545, Giovanni Calker, pittore fiammingo molto raro, e tanto practico nella maniera d' Italia, che le sue opere non erano conosciute 


\section{Martin Kemp}

anatomy . . . later printed in small folio, and engraved on copper, by Valverde' has previously been interpreted as an erroneous (and therefore unreliable) record of either the Tabulae Sex or the Fabrica. However, the most probable and straightforward interpretation of Vasari's text has been overlooked; he was surely referring to the eleven plates of the human figure in the popular Epitome of the Fabrica. And, in his apparently puzzling mention of Juan de Valverde (a Spanish anatomist of the mid-sixteenth century), he was knowledgeably alluding to one of the many anatomical books which were subsequently based upon the text and plates of the Fabrica and Epitome. Two years before the publication of the second edition of Vasari's Vite, large portions of Vesalius's 1543 treatise had been republished in copper engraving and on a smaller scale from Valverde's modified designs. ${ }^{13}$

On the other hand, Vasari's second account almost certainly refers to the more major work, the Fabrica, which was indeed 'sent away' for publication. Vasari's statements are substantially accurate in those respects which can be checked-far more accurate than has previously been allowed. It is not altogether surprising that Vasari should have been well informed on this matter: he had visited Venice (1541-2) at the very time when the illustrations were being completed; he was personally acquainted with Kalkar ('mio amicissimo'), and he considered that Kalkar was of particular interest for his assimilation of the Italian style.

Following Vasari, both van Mander and Sandrart acknowledged Kalkar as the author of the Vesalius illustrations; but, by the middle of the seventeenth century, the attribution of the muscle-men to Titian had begun to gain a firm hold-a hold which it has been reluctant to relinquish. ${ }^{14}$ Historians of science have been delighted to find an artist of such stature involved with the art of anatomical illustration, but they have failed to pay due attention to the incongruity of the illustrations in Titian's oeuvre; whilst historians of art have unjustifiably failed to pay due attention to the unexpected emergence (and potential influence) in Venice of such magnificent expositions of the human figure.

The Fabrica was, first and foremost, Vesalius's own treatise; all the plates, no matter who was responsible for their draughtsmanship, are full of his scientific erudition. The charts of the vessels and the nervous system-diagrams which could only have resulted from the combined data of many dissections, rather than from an

per mano di fiammingo; ma costui mori giovane in Napoli, mentre si sperova gran cose de lui: il quale disegno la sua notomia a Vesalio.'

Prior to his mention of Giolito (in ' $a$ '), Vasari had briefly assessed the work of Marcolini da Forli. Guerra, op. cit., p. 38ff., interprets this to mean that Kalkar's designs were engraved in Marcolini's workshop. However, this section of the Vite is a characteristic Vasarian 'shopping list' of diverse artists, who should not in any sense be regarded as collaborators, although they are mentioned in close proximity.

13 J. de Valverde, Vivae Imagines partium corporis humani aeris formis expressae. (Et Andrae Vesalii suorum De humani corporis fabrica librorum epitome. Item Iacobi Grevini Partium corporis . . . breuis elucidatio), Antwerp, 1566. Valverde's designs are stiffer and flatter than the Fabrica illustrations. However, a few of his plates exhibit a greater degree of independence from Vesalius than is indicated by his introduction: 'Parauimus enimvobis has Valuerde ari insculptas tabulas are vix credibili: earunq' indices fideliter in latinum idioma transuersi curauimus; diligessimusq', ad maiorem facilitatem, in libros septem: quo scilicet ordine ille suum opus digesserat. quod quidem uniuersum conuerters, necesse non fuit; cum fere totum ex Vesalio sit transcriptum . $\therefore$ For Valverde's other works, see F. Guerra, 'Juan de Valverde de Amusco . . . Clio Medica, 1967, 2, 339-63.

14 K. van Mander, Het Schilderboeck, Haarlem, 1604, No. 20; and J. von Sandrart, Teutsche Academie der Edlen Bau-, Bild, un Mahlerey-Kunste, Nürnberg, 1675, VI, xlvi. For a survey of the Titian attributions, see Saunders and O'Malley, op. cit., p. 27. 


\section{A Drawing for the Fabrica; and Some Thoughts upon the Vesalius Muscle-men}

artist's 'photograph' of a single body-must have been planned substantially by Vesalius himself, on the basis of his already extensive dissection experience. Furthermore, in a number of places, the illustrations and corresponding text still echo the persistent notions of the Galenic tradition-notions of which an artist such as Kalkar (or Titian) is unlikely to have been aware.

The remarkable system of 'continuous revelation' employed in the muscle-men could likewise have only been manipulated in the necessary detail by Vesalius, since the muscle-men are ultimately organized on a minutely methodical basis of scientific description. The underlying method of book two is simple enough. Two factors have changed between one plate and the next: progressively deeper structures have been revealed by the removal of the overlying tissues; and the three-dimensional relationships of the various parts have been clarified by the ingeniously controlled changes of pose. Vesalius's system is beautifully economical. In co-operation with his draughtsman, he has brilliantly been able to reconcile his wish not to tax the reader with an excessive number of plates with an amazingly fluent and complete description of human musculature, from various aspects and according to the attachments of each muscle. ${ }^{15}$

The methodic economy of Vesalius's plates cannot better be demonstrated than by comparison with Leonardo's most advanced and heroic attempt, some thirty years earlier, to achieve a similar degree of completeness. Towards the end of his career, Leonardo had become dissatisfied with his early system of three or four right-angle views to survey the structures of the human body. The rigidity of these surveying methods of presentation, which he had adapted from his architectural practice, had broken down under the increasing organic complexity of his anatomical studies after 1510. ${ }^{16}$ Unlike Vesalius, however, he was not prepared to move away from this triply repetitive method towards a more economical series. Rather, Leonardo yet further elaborated the three-part pattern into a continuously 'cinematographic' technique, in which each form was to be viewed from at least eight successive angles. The drawing in the Royal Collection at Windsor (fig. 4), which shows (from right to left) the first four dimostrationi in the series, gives the clearest idea of this method in action. The small, stellate diagram below the first figure shows that he was still fully committed to a basically geometrical theory of perfectly optical completeness. Astonishingly, he indicated his intention to execute eight more drawings of the same dissection, with the radius and ulna crossed (i.e. with the wrist rotated). ${ }^{17}$

Leonardo was not prepared to strike a workable compromise between reasonable practicality of presentation and absolute completeness of visual survey; he was irrevocably committed to the impossible task of leaving nothing unrepresented, no spatial relationship in doubt, and no corner visually unexplored. This perfectionism could only lead to a potentially infinite proliferation of diagrams. And, inevitably, Leonardo's magnificent vision was unrealized (and unrealizable) in practical terms.

\footnotetext{
2s For Vesalius's statement on the avoidance of excessive illustration, see Fabrica I, vi.

10 Compare, for example, nos. 12619 and 19003v in the Royal Collection at Windsor. See $\mathrm{K}$. Clark, A Catalogue of the Drawings of Leonardo da Vinci at Windsor Castle, rev. ed., Clark and Pedretti, 3 vols., London and New York, 1969; and a forthcoming article by the author.

12 The four remaining demonstrations in the first series of eight are on Windsor 19005v. The stellate diagram is derived in part from J. Peckham's Prospectiva Communis.
} 


\section{Martin Kemp}

Vesalius had similarly begun, in the three skeletons of the Tabulae Sex, with a system of anterior, posterior and lateral views. However, his subsequent system, which only occasionally permitted itself the expansive luxury of a three-part representation of the same dissection, sacrificed Leonardo's absolute completeness in favour of a less visually exhaustive (and exhausting) approach. Vesalius's method was, above all, that of a practical anatomist. At each fluent move from one plate to the next, he has carefully balanced the two variables (the differing degrees of anatomization and the variations of pose), weighing the demands of visual completeness against the continued momentum of dissection. The two changing factors are interrelated with the greatest subtlety. Whoever was responsible for the actual draughtsmanship of the final plates in the Fabrica, the detailed scientific co-ordination and intellectual direction of the muscle-men can only be acredited to the master-mind of the anatomical series as a whole, Vesalius himself.

The necessary dominance of Vesalius's intellectual and creative impulses could have provided one of the reasons for the lack of credit in the Fabrica to the artist or consortium of artists involved. The task of the artist(s), in the more formally complex Fabrica and Epitome illustrations, would basically have been to provide the standards of draughtsmanship and presentation which Vesalius could not fully contribute himself. But the executant(s) of the muscle-man series succeeded so completely in reconciling this artistic requirement with Vesalius's (no doubt precise) demands for anatomical lucidity, that the roles of Vesalius and of his designer(s) are not easily separable in practice. The author of the red chalk drawing would have been required to work over a considerable period of time in the closest possible co-operation with Vesalius, almost certainly in Padua, where Vesalius was teaching, and undoubtedly under Vesalius's supervision at every stage in the design.

It is difficult to see Titian, at this stage of his career, performing this highly specialized function. And, if Titian had indeed played a significant role in the creation of the plates, it is hard to imagine that the young anatomist or his publisher would not have been keen to publicize the participation of this most famous painter.

The extant drawing for the second muscle-man can be shown to have occupied a genuinely intermediate stage in the intricate process of creative co-operation between Vesalius and his draughtsman. The drawing's actual position in this process can be definied with some accuracy by reference to the series of plates in which it was destined to take its place.

The 'Second plate of the muscles', to which the drawing corresponds, is one of the comparatively rare instances in the Fabrica of a second representation of a single dissection. Vesalius acknowledged in his note that the second plate corresponded exactly to the first since it represented the same dissection, but from the lateral aspect. ${ }^{18}$ The introduction to the first plate (fig. 5) had indicated that the early illustrations in the muscle-man series, showing similarly superficial dissections, were intended to display a total view of the major muscles 'such as only painters and

\footnotetext{
18 'Secunda tabula primae, quod ad sectionem spectat, omnio correspondet, et in latus uersa eosdem cum illa commonstrat at musculos, una cum ossium sedibus in superficie promentibus, ac ut sic dicam, excarnibus.'
} 


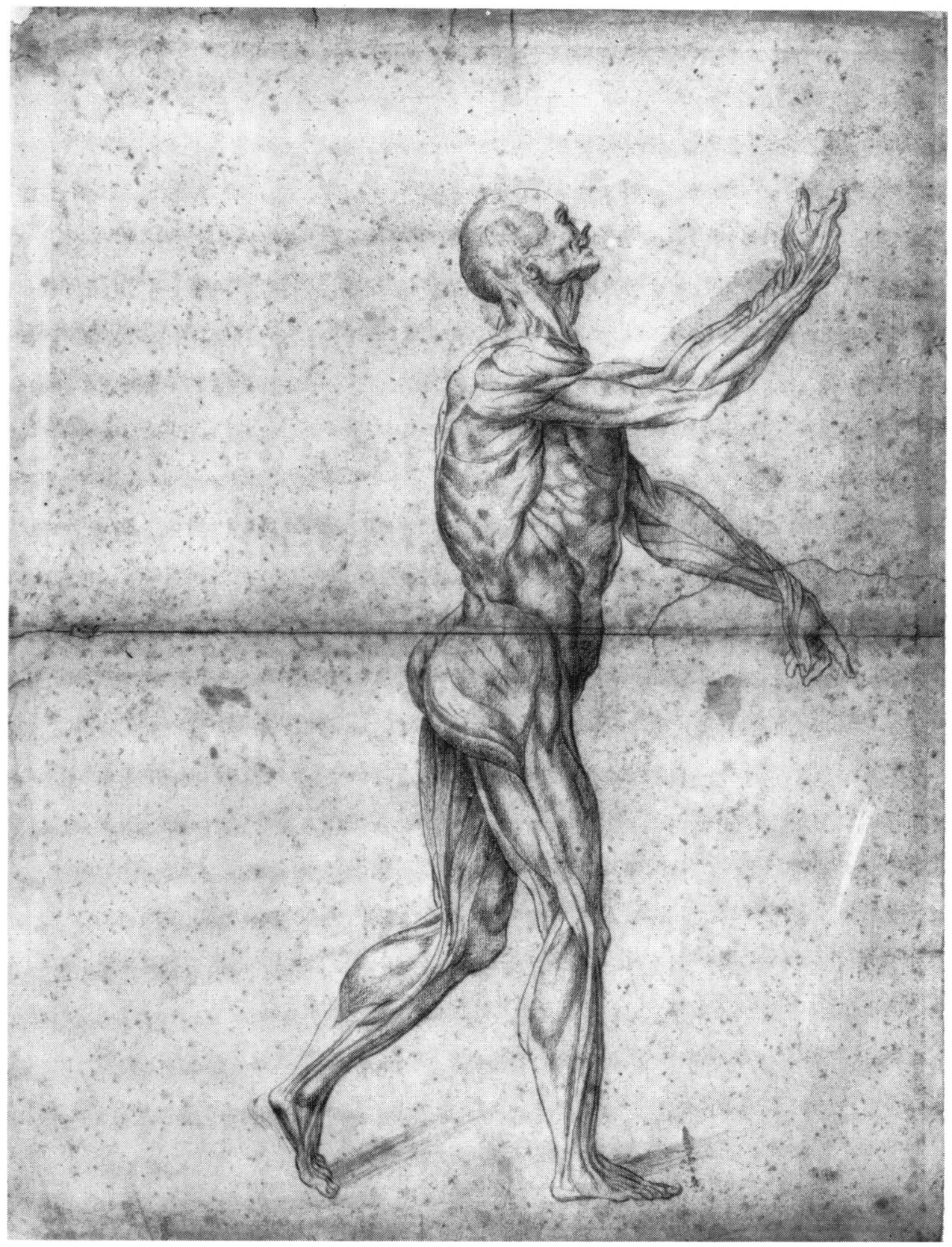

Figure 1

Anatomical study for Vesalius's Fabrica, red chalk. In the Rudolph S. Joseph collection, Munich, and reproduced by kind permission. 


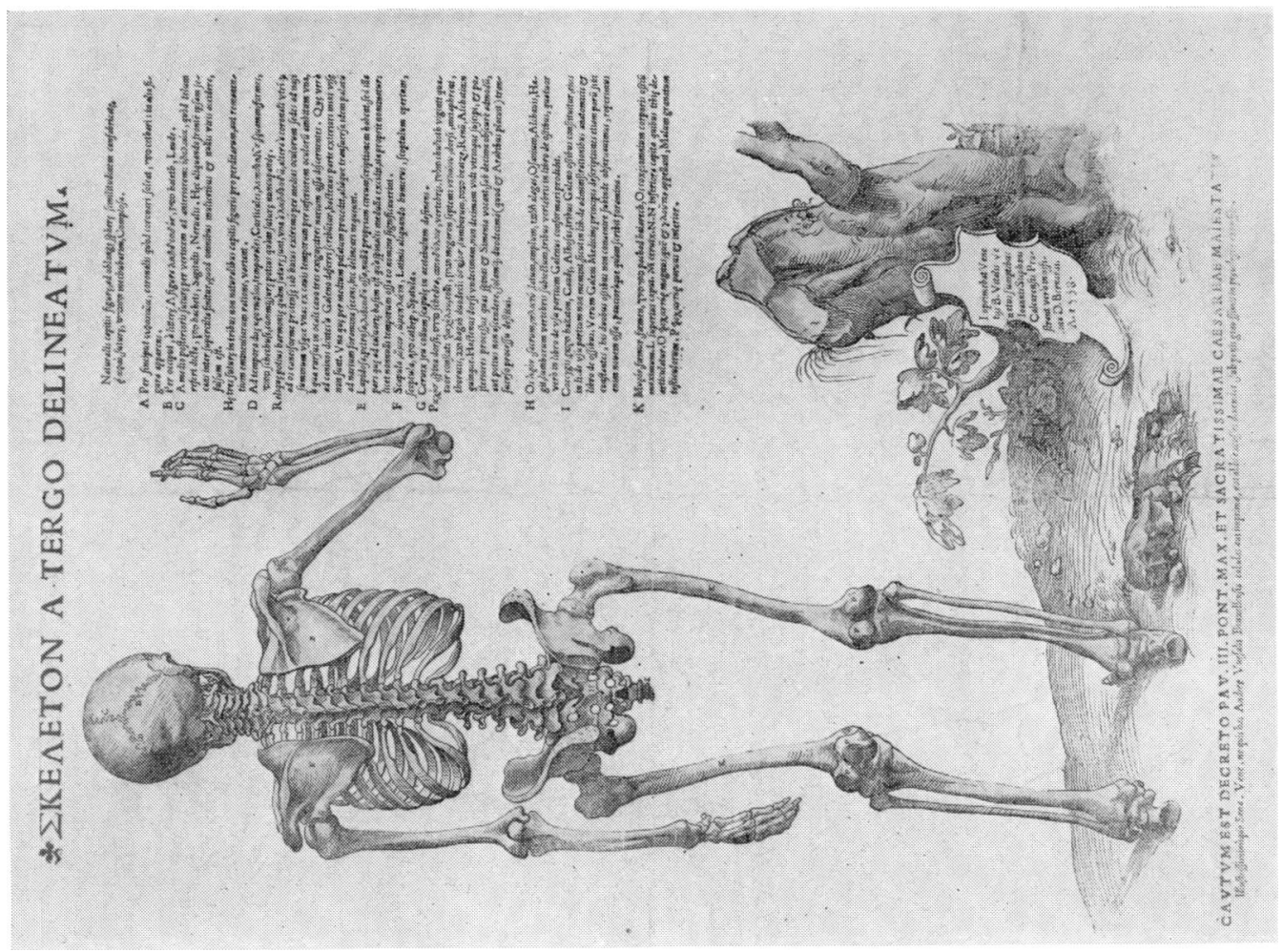

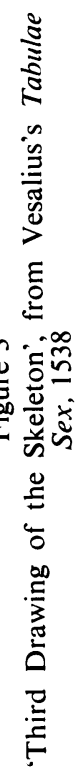

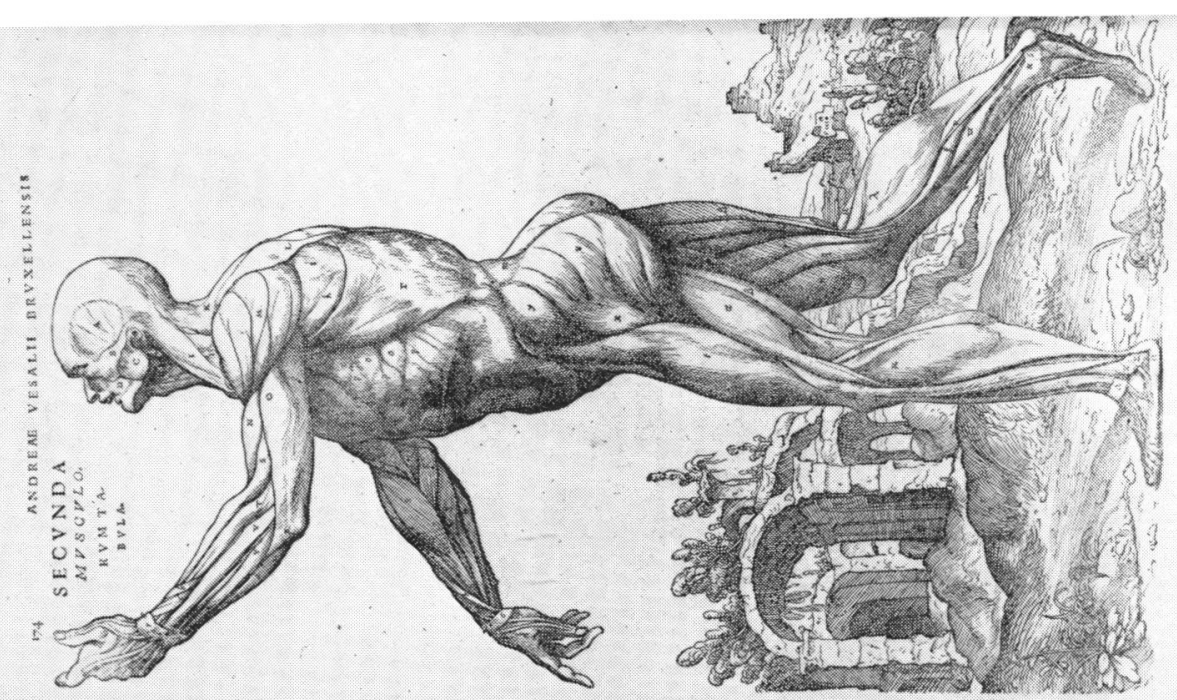

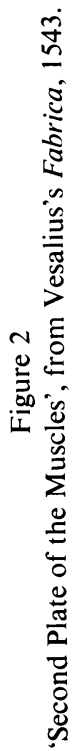




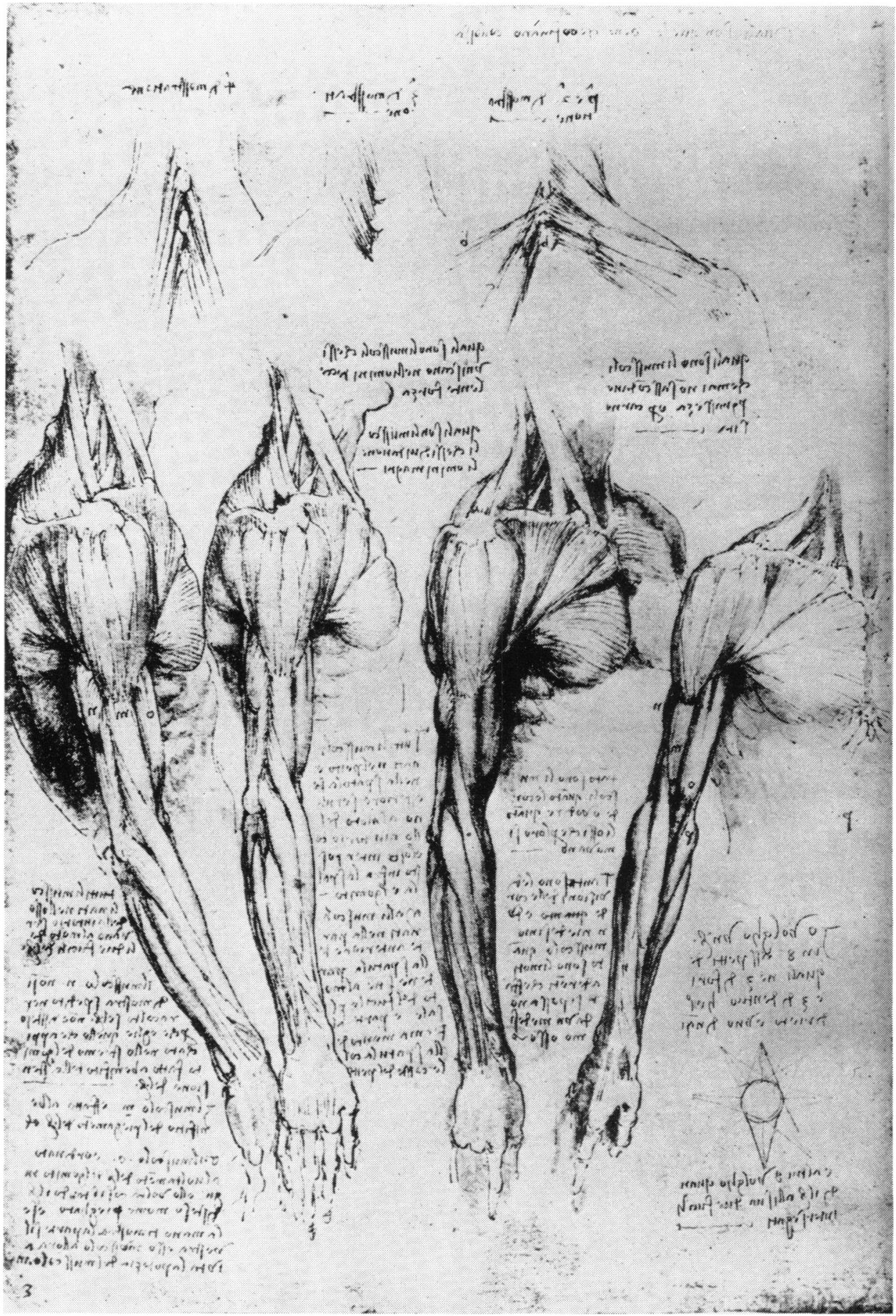

Figure 4

Leonardo da Vinci, studies of the shoulder and arm, pen and ink. In the Royal Collection, Windsor, no. $19008 \mathrm{v}$, and reproduced by gracious permission of Her Majesty The Queen. 


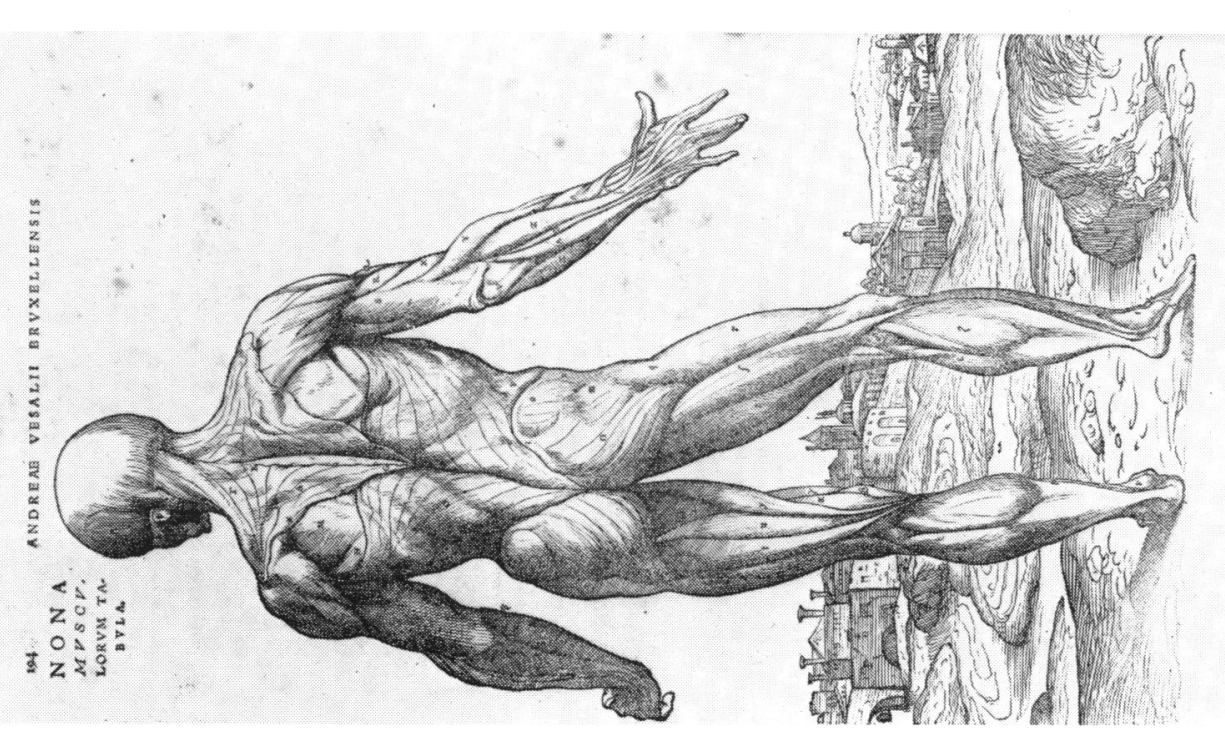

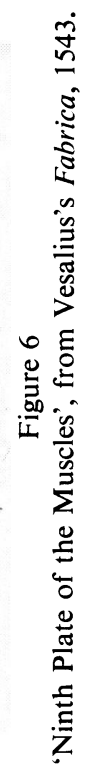

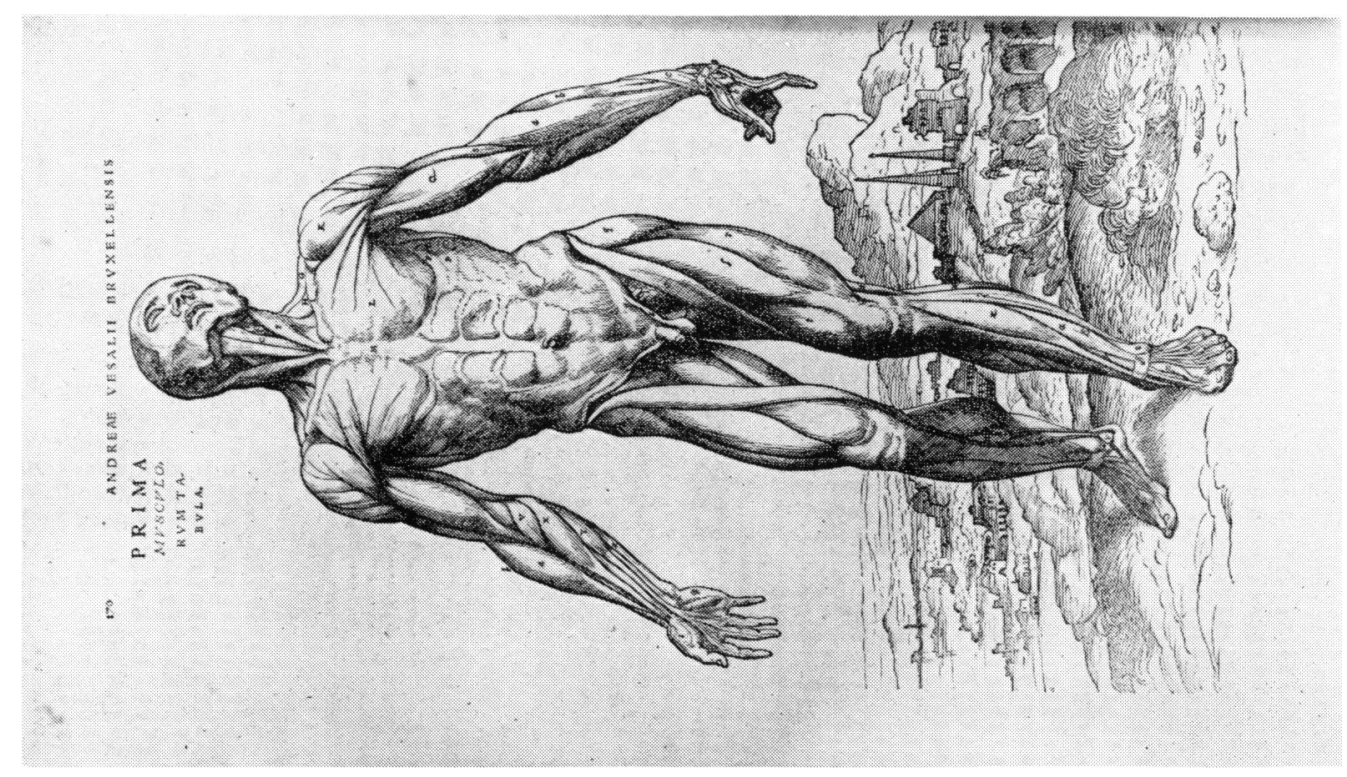

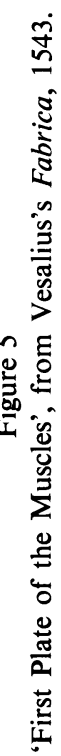



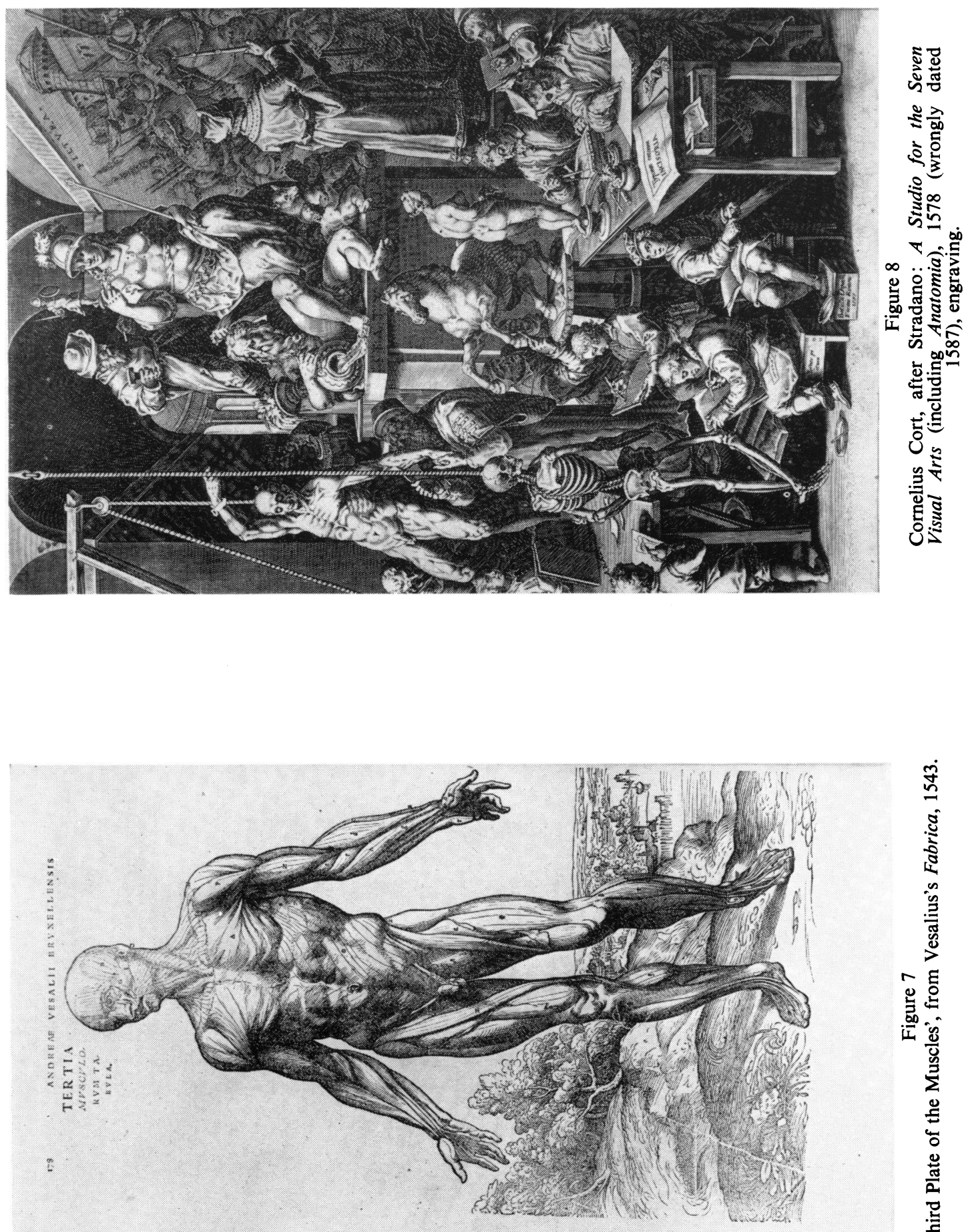

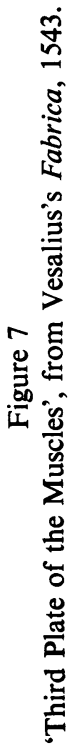



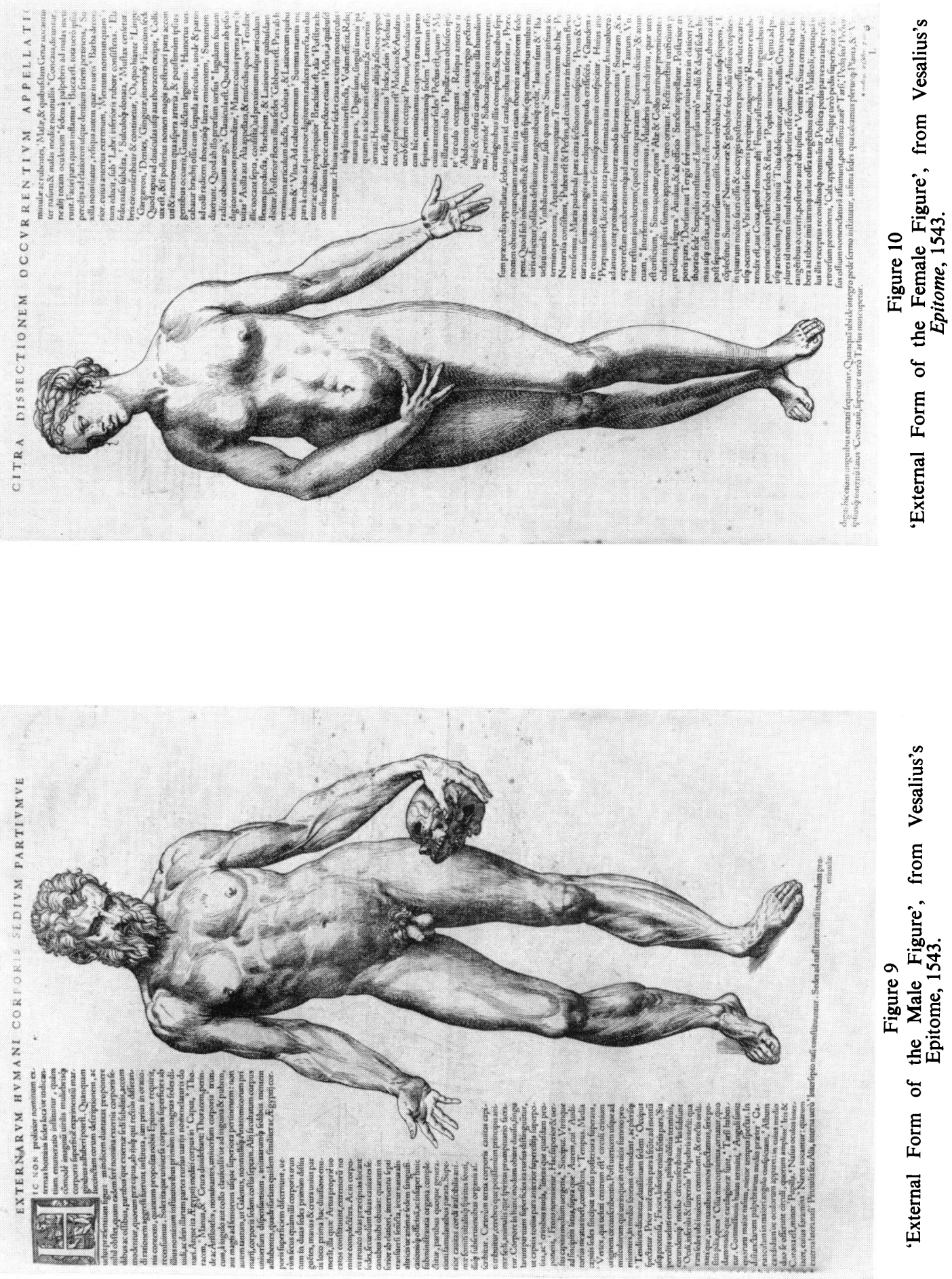

告

온

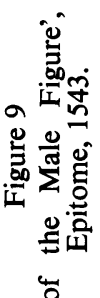

¿ั

폼 

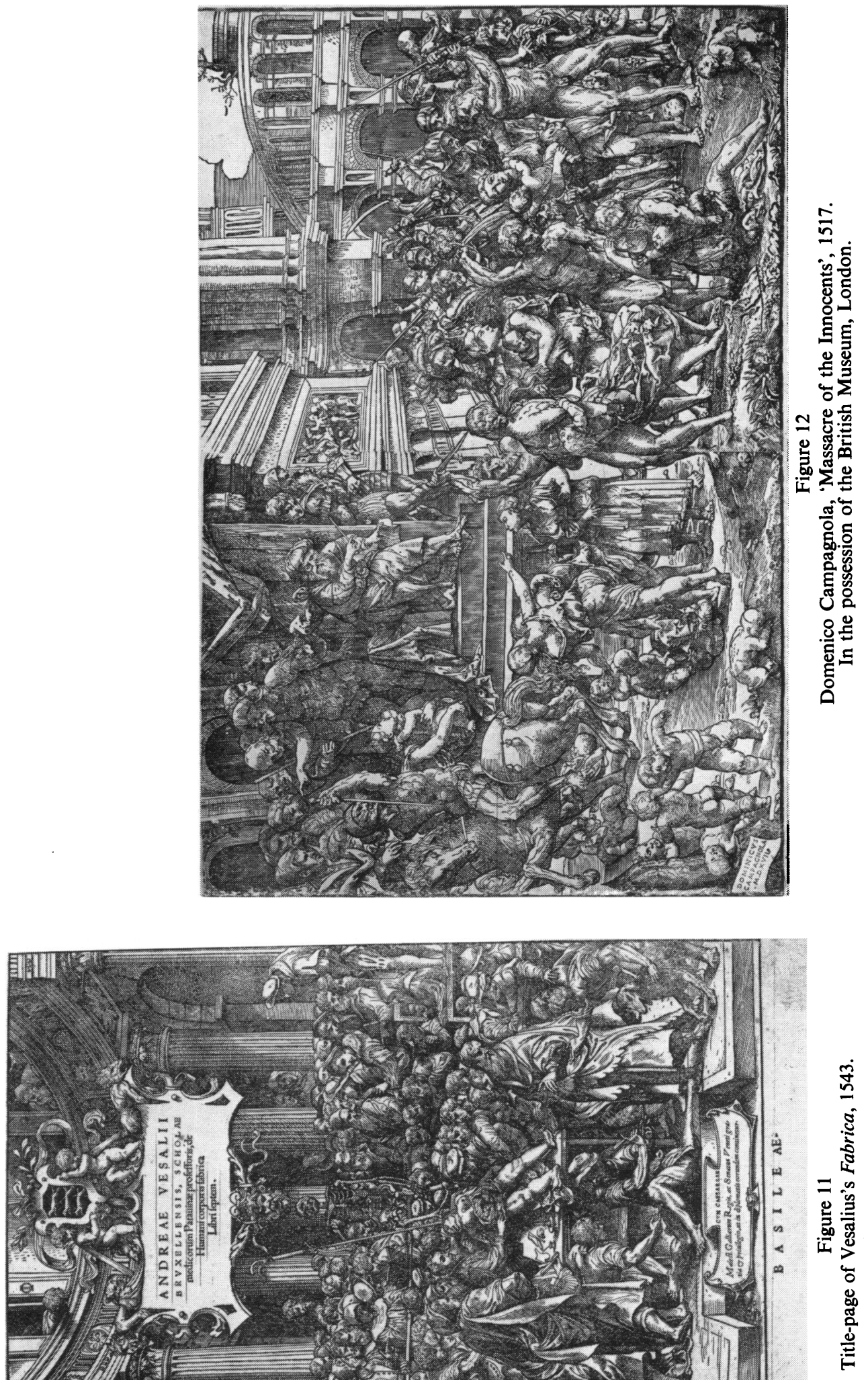


\section{A Drawing for the Fabrica; and Some Thoughts upon the Vesalius Muscle-men}

sculptors would normally consider' ${ }^{19}$ Vesalius presumably wished to open his series with a reasonably complete picture of the muscles in situ. However, of the early stages-numbers one, two, three and nine-only the first two show identical states of anatomization. In plate nine (fig. 6), which correspondingly opens the series of rear views, Vesalius has characteristically taken the opportunity to maintain the momentum of his exposition, by pressing his preliminary dissection a small stage further. Vesalius recorded that he had 'dissected the transverse ligaments which lie on the outer side of the fore-arm'. Were it not for the removed ligaments, the first two plates and the ninth would together comprise a standard system of anterior, lateral and posterior representations of the same dissection. Vesalius was able to justify this minor but significant deviation from the standard practice on the grounds of unnecessary repetition; the ligaments were omitted 'because they were clearly to be seen in the first and second plates'. ${ }^{20}$

Conveniently, from the historian's point of view, these small ligaments provide an invaluable clue to the drawing's exact position in the development of the plates; these ligaments comprise, as already noted, the clearest difference in bodily structure between the study and the second muscle-man. The drawing surprisingly corresponds more closely to the state of dissection in the rear view on plate nine-from which the ligaments have been identically omitted. In a similar manner, the dissection of the ankle ligaments in the drawing can be closely paralleled in the frontal view on plate three (fig. 7); in the plate, the ligament of the figure's left foot has been hinged back to reveal its attachment, and that on the right has been removed, as in the drawing.

In view of these unexpectedly close correspondences in detail to dissections other than the second in the series, it can be inferred that the drawing represents a stage prior to the final and minutely detailed orchestration of the anatomical progression from one plate to another. After the completion of the study, and before the execution of the woodcut, the vital decisions of clarification and co-ordination must have been taken.

The plates of the Fabrica, in their final arrangement, do not follow a simple linear progression from superficial to deeper structures. The third plate, as Vesalius noted, 'demonstrates the anterior view of the body, and it differs from the first plate of the muscles in that it shows the muscles of the fleshy membrane, and also several of the facial muscles'. ${ }^{21}$ The fleshy membrane ('membrana carnosa') would originally have lain above the major muscles in plates one, two, and nine. In this respect, plate three represents a more superficial degree of anatomization than the two preceding

10 'Hanc tabulam una cum sequenti, characteribus liberam reliquere propositum erat, quo minus illis commaculata spectaretur. Quandoquide tertia fere prima est, quam ad disciplinam parauinus, preasens namq'; (utinec consequens) aliquid oculis subijcit, quod non in musculosis, \& quadratis, ut sic dicam, homininbus, eruditos pictores sculptoresq; indies etiam praecipue emprimere obseruamus. Quae enim membrana in tertiae tabulae facie \& ceriuce uisuntur, \& fibrae etiam musculis ductae, potius pictorem, ac scltore \& plastem (quorum studijs quod; opitulari usium est) peturbant.'

${ }_{20}$ 'Praesens tabula omnium posteriorem corporo facim experimentiu, prima habebitur, hic ordine non a. Sitamen anterioribus seriatum ac uicissum posteriores subsequi uelles, posset haec ominium esse aut tertia, aut quarta, nullum enim absectu, habet musculum, praeter cos, quoa carnea membrana constituit, tertiaq; tabula obuij sunt. Praeterea transuersa in cubiti, externa sede, iuxta brachiale reposita ligamenta hic disseciumus, quod prima \& secunda tabulis abunde conspicua suerint, hancq; tabulam ad disciplinam prorsis parauerimus.'

21 'Praesens tabula anteriorem corporis faciem experimens, in hoc a prima musculorum tabula differt, quod musculos ex carnosa membrana costituos \& aliquot etiam faciei musculos ad adipe liberatos commonstret, quodq; magis ad musculorum disciplinam, quam priores duae sit comparata.' 


\section{Martin Kemp}

illustrations. But the transverse ligaments have been dissected and the facial muscles have been revealed. The third illustration shows a stage earlier than plate one, in its retention of the fleshy membrane, and more advanced than plate one, in its omission of the ligaments and differentiation in the head.

In the second plate, the structures of the head, most particularly the muscles of the jaw, are more clearly displayed than in the preparatory drawing. The head of the drawing is actually closer to the state of dissection in plate one. The heads in the four plates and the study can thus be grouped in the following order (from superficial to deeper dissections): plate one and the drawing; plate three; plates two and nine. The ligaments provide a different sequence: plates one and two; plate three; the drawing and plate nine. And the fleshy membrane yet another: plate three; plates one, two, nine and the drawing. The ultimate decisions for anatomical progressions of this complexity can only have rested, after the completion of similar drawings for each muscle-man, with Vesalius himself.

Vesalius stated that the muscle-men were drawn by the artist directly from the dissected cadavers which the anatomist held upright by means of a contraption of ropes and pulleys. ${ }^{22} \mathrm{~A}$ set-up of just this kind was portrayed some thirty-five years later by Cornelius Cort in his engraved version of Stradano's factory-school for the visual arts (fig. 8). The preliminary drawing for the Fabrica may well have been a carefully supervised product of this method of direct representation. But the final result in the second plate of the series cannot simply be regarded as the artist's second representation of a single figure in a dissection series. Each plate is the joint culmination, over a considerable period, of Vesalius's meticulous research into the human body and of his equally meticulous research into the appropriate means for the detailed exposition of his results. This arduous creative process of minute refinement and readjustment-a process with which the artist of the red chalk drawing must have become intimately involved-was of the utmost intellectual and representational complexity.

The style of the drawing is tightly precise. The pentimenti-the relatively conspicuous adjustment behind the rearmost heel, and the minute manoeuvring for position in areas of the torso-are of a fussily delicate and careful kind. The contours of the muscles have been rigorously defined by incisively firm outlines, and their internal modelling has been accomplished by a controlled use of blended tones. The overall silhouette of the body has not been conceived in a fluently rhythmic manner. Rather, the contours of the figure meticulously obey the irregular profiles of the exposed muscles. The figure is satisfactorily articulated in most respects, with the exception of the rather weakly drawn feet-a minor fault which the drawing shares with the Tabulae Sex skeletons, the Epitome nudes, and a number of the muscle-men.

Parallels for such a subtle yet definitive use of red chalk can only be found before this time in the art of central Italy, most notably in the drawings of Leonardo, Andrea del Sarto and those draughtsmen who followed their lead. ${ }^{23}$ But the particular

\footnotetext{
"2s Vesalius's description of his method is recorded by Saunders and O'Malley, op. cit., p. 29. The 'Seventh plate of the muscles' shows 'the rope from which the body was suspended during delineation.'

2 Leonardo used red chalk most regularly for his anatomical studies at the time of his work on the Battle of Anghiari, particularly favouring this method for his representations of surface musculature (Windsor, 12623, 12625, 12629, 12594, and 12596).
} 


\section{A Drawing for the Fabrica; and Some Thoughts upon the Vesalius Muscle-men}

qualities of outline in the drawing, almost pen-like in the arms and legs, are closer to those of an artist in the Northern European tradition, of an Italianate draughtsman in line of descent from Dürer and Mabuse to Floris and Goltzius.

Direct stylistic comparisons with Venetian drawings are difficult to make. There are no extant drawings by Titian (or by his Venetian contemporaries) of the careful kind required for such definitive illustrations. But, even at his most anatomical, Titian gives no hint of a technique similar to that of the Fabrica study. ${ }^{24}$ Compared to the instinctive sprezzatura of the known Venetian style, the drawing is (even when due allowance has been made for its function) notable for its measured control of detail. All that can be said, under these circumstances, is that the stylistic clues point away from Venice in general and away from Titian in particular.

It is just conceivable that the studious author of the red chalk drawing may also have been responsible for the backgrounds. However, in view of the wholly Venetian vigour of the landscape details, this is rather unlikely. The grassy hummock in plate one and the thicket of trees in the third plate, for instance, are energetically conceived in the Venetian manner of freely open rhythms. Comparably non-anatomical details in the figures-suitable examples are provided by the decorative hair on the dissected heads in book seven and by the hair of the Epitome nudes (figs. 9 and 10)are executed with a careful linear precision. The expansive and mobile conception of form in the landscape details seems to be of an entirely different order from the self-enclosed, almost finical outlines of the red chalk study. Even allowing for their essentially decorative function, the landscapes appear to possess a fundamentally different pedigree from the figures. The landscapes stand completely within the Venetian tradition of Domenico Campagnola. ${ }^{25}$

In the absence of suitable comparative material, such analyses of technique cannot alone establish the identity of the artist of the muscle-man series, but if these formal criteria are taken in conjunction with the documentary clues, certain distinct probabilities begin to emerge.

From what little we know of Jan van Kalkar's background-he was trained in Flanders and probably did not enter Titian's bottega until he was at least thirty-five years old-it is possible to infer that his creative methods would not have been identical to those of a native Venetian painter, no matter how similar the final effects of his work might have been. ${ }^{26}$ Vasari mentioned Kalkar as a practitioner of portraiture, a genre for which the naturalistic artists of the North were then considered

" See H. Tietze and E. Tietze-Conrat, The Drawings of the Venetian Painters, New York, 1944, for Titian in particular (nos. 1915 and 1906 are the most anatomical), and more generally for their unrivalled grasp of Venetian draughtsmanship.

${ }^{25}$ For Campagnola, see H. Tietze and E. Tietze-Conrat, 'Domenico Campagnola's graphic art', Print Collectors' Quarterly, Oct. 1939, pp. 310-33 and 445-69; and The Drawings of the Venetian Painters, pp. 122-32.

26 The scanty biographical details of Kalkar's career have been assembled by F. M. G. de Feyfer, 'Jan Steven van Calcar, 1499-1546', Nederlandisch tidjschrift voor geneeskunde, 1933, pp. 3562-79. The small Rhenish town, Calcar (near Vesalius's birthplace, Wessel), was notable in Renaissance art for the activities of Jan Joest. In Flanders, Kalkar had been a pupil of Jean de Bruges, probably before 1520 (providing that the 1499 birth-date is correct); and he appears to have worked in Titian's bottega, surely not as a pupil, during 1536-7. He was active as a portraitist in Naples by 1545 . No Italian paintings can be attributed with any certainty to Kalkar, and his pre-Italian style is undocumented. 


\section{Martin Kemp}

to be especially well suited. Vasari also considered that Kalkar had desirably assimilated the 'maniera d'Italia' in figure style (presumably the key virtue of Florentine disegno) to a degree which was unusual in a foreign painter. Kalkar was in Venice at the time when central Italian draughtsmanship, through the Salviatis and Vasari himself, was making itself most keenly felt. ${ }^{27}$ Also, the possibility of an earlier trip to central Italy cannot be discounted; a pilgrimage to Rome was becoming an almost obligatory act for an ambitious Northern artist of the mid-sixteenth century.

Kalkar, like so many of his fellow expatriates, may have been tempted to strive towards the reconciliation of the heterogeneous factors in his background, attempting to combine elements from Flemish naturalism, Titianesque monumentality and Salviatian disegno. Such an attempt would be fully consistent with Vasari's approval of his friend's accomplishments in 'small as well as large figures'. And it is entirely commensurate with the actual style of the red chalk drawing. Since the documentary evidence also lends some slight support to the thesis of Kalkar's participation in the Fabrica designs, it is reasonable to suggest that the drawing for the second muscleman should be provisionally attributed to Jan Steven van Kalkar. The existing clues do not indicate any wholly feasible alternatives.

As Saunders and O'Malley have rightly stressed, the landscapes of the Fabrica possess much in common with the style of Domenico Campagnola. It must be noted, however, that Campagnola appears not to have been a member of Titian's bottega; and his possible designing of the landscapes cannot be used in support of their claim that the Fabrica illustrations originated from Titian's studio. ${ }^{28}$ Nor can their verification of Cushing's proof that the backgrounds form 'a continuous landscape' be accepted as it stands. ${ }^{29}$

The Campagnolesque nature of the Fabrica woodcuts emerges most strongly in the title-page (fig. 11). The use of gesture and expression in the Vesalius dissection scene is strikingly similar to that in the group of spectators in Campagnola's early Massacre of the Innocents (fig. 12). And the densely-packed excitement, so unexpected in the title-page, was one of the uniquely individual characteristics of Campagnola's style as manifested in the Massacre.

If Campagnola was indeed the artist of the landscapes and the title-page, he may also have been the actual engraver of the plates. It would have been simpler (and more logical) for Campagnola, as a master woodcut artist, to have taken over all the final stages in the book design-the appending of the landscapes, title-page and decorative initials in the text-cutting the wood blocks himself, rather than passing the various components to yet another artist for engraving. The execution of the figures-the vigorously dense cross-hatching and the delicately 'flicked' shorter strokes-is, within certain limits, consistent with Campagnola's known technique. The controlled subtlety of the red chalk drawing has been partially but perceptibly 'Venetianized' in the plates by a more energetic technique and by an amplification

${ }^{27}$ See R. Palluchini, La giovinezza del Tintoretto, Milan 1950, pp. 36-46; and J. Schulz, 'Vasari in Venice', The Burlington Magazine, 1961, pp. 500-11.

28 Op. cit., p. 29.

${ }^{29}$ Cushing, op. cit., p. 87. The apparent continuity of some (but not all) of the plates probably results from the basing of the landscapes upon a limited number of closely related sketches. But, in the final treatise, the landscapes cannot be regarded as continuous in any deliberate or obvious sense. 


\section{A Drawing for the Fabrica; and Some Thoughts upon the Vesalius Muscle-men}

of rhythmic contour. Such adventitious vigour is not an inevitable attribute of the woodcut medium; the woodcuts of the Tabulae Sex possess little of this extra physical assertiveness.

However, the 'Venetianization' of the figures is far from complete. The landscapes and the muscle-men obstinately retain their fundamentally different design characteristics. Specifically non-Venetian qualities can be discerned in the more complete figures. Their consciously poised grace of movement and the eloquently stylish gestures of their hands are directly dependent upon the maniera of central Italy. But it is only in the undissected nudes of the Epitome that these qualities come entirely to the fore.

Although the poses of the nudes are related to the other illustrations in the Epitome, they are not part of an extended series in which poses and states of anatomization are minutely choreographed. They may, therefore, be regarded as clearer visual evidence of their creator's 'normal' figure style than the more exclusively anatomical plates. What is most striking about these independent nudes, besides their unusually large scale and extremely high quality, is their lack of real affinity at this date with the Venetian style in general, or with the style of Titian in particular.

The female figure is Parmagianinesque in form and feature, with, perhaps, some hint of Northern European proportions in her smallish breasts and large abdomen. Only in the late 1550s does Titian adopt a canon of attenuated elegance comparable to that of the Epitome 'Venus'.$^{30}$ The robust yet elegant form of her male companion may well reflect the influence of the Salviatis. The head of the male figure is basically non-Venetian (even non-Italian) in type; the crisp curls of his beard and the curving waves of his hair have been executed with an almost metallic sharpness, more akin to Dïrer's copper-plate style than to the Venetian woodcut bravura which can be discerned in the shading of the torso. In the hair, the underlying design characteristics of a non-Venetian drawing style appear to have outweighed the Venetian technique of the woodcut artist.

The style of the Epitome nudes, like that of the red chalk drawing, suggests that their designer may well have been an artist of Kalkar's heterogeneous background.

The exceptional standard of the Fabrica and Epitome illustrations, as much as any other factor, has been responsible for the numerous efforts to identify their designer as Titian. The quality is undoubted, but it is not the quality of the Titian we know. The 'characteristics of Titian observable in the figures' have often been inferred but never convincingly elucidated.31 If Titian's datable paintings of the period are examined with the Fabrica and Epitome in mind, the resulting conclusions are, I believe, precisely the opposite of the customary account.

Titian's paintings of the early 1540s are indeed more 'anatomical' than those of the immediately preceding period; but when this development is examined in detail it can be shown to follow by some two years the completion of the muscle-men (1541), rather than to be contemporaneous with their execution. His figure style prior to the Fabrica had moved away from Michelangelo's influence towards a use of more

20 Most particularly in the stories of Diana, painted in 1559 for Philip II of Spain, now in the Bridgewater Collection. See H. Tietze, Titian, Drawings and Paintings, London, 1950.

$\$ 1$ Saunders and O'Malley, op. cit., p. 28. 


\section{Martin Kemp}

generalized form. ${ }^{32}$ The reversal of this trend in favour of a style more akin to that of Florence and Rome can be partially equated with the challenge of Pordenone and with the influence of the Salviatis. The Ecce Homo, signed and dated 1543, is the first precisely datable work which openly reflected the impact of their art. ${ }^{33}$ Around this painting can be grouped a number of closely related but undated works, all of which exhibit some features of his 'new' manner. ${ }^{34}$ These paintings do not really indicate that Titian could have been responsible for the design of the muscle-men series; his broadly synthetic treatment of form always remains dominant over any definitive exposition of detail. But they do suggest that Titian was sensitive to the physical power of the illustrations and that he was responsive to their high degree of anatomical conviction.

During the early 1540s, the confrontation between the styles of Venice and Florence had reached a crucial stage, particularly for a young artist such as Tintoretto. The muscle-men were undoubtedly of the quality to have played a not unimportant role in the resulting reaction. The influence of the Fabrica upon the art world has yet to be charted; but there is evidence to suggest that it retained its hold as a source book for artists until the early nineteenth century. ${ }^{35}$

Whoever was responsible for the consummate artistry of the muscle-men, and whatever their subsequent influence, we can be certain that the process of their planning, design, delineation and execution represents one of the most remarkable achievements in the history of anatomical art and in the art of anatomical illustration. The relationship in the Fabrica between the practice of visual representation and the science of anatomical demonstration could not have been closer-as is shown by the complex formal and scientific relationships between the drawing and the plates.

At present, we cannot categorically assert that the ability to achieve such a standard lay either within or outside the scope of the little-known Kalkar; but the documentary and visual evidence is gently inclined in favour of his authorship of the muscle-men.

\footnotetext{
32 See the Michelangelesque St. Sebastian of 1522 (Brescia, SS. Nazaro e Celso), and the St. Sebastian in the San Niccold dei Frari Altarpiece, c. 1538 (Rome, Pinacoteca Vaticana), illustrated by Tietze, op. cit., pls. 58 and 145 .

23 Vienna, Kunsthistorisches Museum.

34 The Crowning with Thorns (Paris, Louvre), St. John the Baptist (Venice, Accademia), the Sacrifice of Isaac, Cain and Abel and David and Goliath (Venice, S. M. della Salute).

${ }_{25}$ See, for example, W. Robertson's introduction to Flaxman's Anatomical Studies of the Bones and Muscles, London, 1833, p. 6.
} 